\title{
EFFECT OF TILLAGE SYSTEM AND SEEDING RATES ON GROWTH AND WHEAT YIELD Triticum aestivum L. AND ITS ASSOCIATED WEEDS.
}

\author{
Salim H. Antar Ahmed M. Almashhadany \\ Feld Crop Dept., College of Agriculture and Forestry, University of \\ Mosul, Iraq \\ E:mail Ahmed3079560@gmail.com
}

\begin{abstract}
The experiment was carried out during the winter agricultural season 20182019 in Nineveh Governorate at two location (Hamdaniya district 25-30 km east of Mosul and Talkif district 25-30 km north of Mosul), the experiment include two factors, tillage systems (conservation and conventional tillage) and seeding rates $\left(80,100\right.$ and $\left.120 \mathrm{~kg} \cdot \mathrm{ha}^{-1}\right)$, the seeds were planted at $11 / 1 / 2019$ and 12/1/2019 for the two locations respectively. The variety Adana registered certified by Ministry of Agriculture was used. The experiment was applied as factorial experiment using split plots system by R.C.B.D with three replications. The main plots contained the two tillage systems levels, and the sub plots contained seeding rates levels, the experimental unit area was $20 \mathrm{~m}^{2}$, The results showed no significant differences between tillage system in number-of narrow and broad leaves weeds and their weight for two location but the conservation tillage was surpassed conventional for grain yield by 78.57 and $119.52 \mathrm{gm} . \mathrm{m}^{-2}$ in Hamdaniya and Talkef location respectively, non-significant differences between the seeding rates in no-of narrow and broad leaves weeds for two location, but seeding rate $120 \mathrm{~kg} \cdot \mathrm{ha}^{-1}$ surpassed 80 and $100 \mathrm{~kg} \cdot \mathrm{ha}^{-1}$ for grain

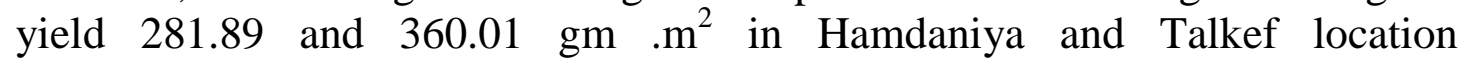
respectively. Non-significant differences between the seeding rates with conservation or conventional tillage in narrow leaves weeds for two location but lower number-of broad leaves weeds in seeding rate $120 \mathrm{~kg} \cdot \mathrm{m}^{-2}$ with conservation agriculture for two location. The best grains yield obtain with seeding rates $120 \mathrm{~kg} . \mathrm{h}^{-1}$ and conservation tillage by 314.62 and $405.02 \mathrm{gm} . \mathrm{m}^{-2}$ in Hamdaniya and Talkef locations respectively.
\end{abstract}

Keywords : Wheat, Tillage system, seeding rates.

Received: 14/6/2020 ,Accepted: 19/7/ 2020

\section{INTRODUCTION}

Wheat is one of the most important crops in Iraq and World, it is grown in a large areas around the world, which reached, according to the FAO organization about 210 million $\mathrm{ha}^{-1}$. The grain yield was about 589 million tons. The crop suffers from low production due to many problems, including

"Part of M.Sc. thesis submitted by the first author . 
the problem of the associated weeds, which competes with crop on moisture and nutrients soil. The determining factor for growth and productivity in the dry areas is humidity (Bhattacharyya et al 2006). The farming system has affected the moisture content of the soil and the growth of the weeds. In the zero tillage system the soil moisture content is high compared to the conventional planting system .In the conventional planting system soil excitation is high according to type of plow used, which leads to an increase in the growth of the weeds early as compared to the conservation agriculture where the soil excitation is low and the percentage of weeds is low. The aim system of conservation tillage works to harvest water and improve the properties and structure of soil and reduce erosion and this is reflected in an increasing production (Blackshaw et al 2007). Seed rate an important process for the management of wheat crop, which affected the yield, field characteristics and productivity of this crop. The high seeding rate increases the plant density per unit area and this raises the competitive efficiency among plants which positively affected on the crop (Lemerle et al 2004) The main objective of increasing the seeding rate is to reduce the number of weeds and their weights through competition between them and the crop plants on the water and nutrients and increasing the yield. seeding rates vary according to species genotypes and environmental locations in terms of climatic conditions and soil nature. The aim of this research is to study the effect of two tillage systems and seeding rates on growth yield at two different environmental locations .

\section{MATERIAL \& METHODS}

The experiment was carried out during the winter season 2018-2019 in Nineveh Governorate two location Hamdaniya district 25-30 km east of Mosul and Telkif district $25-30 \mathrm{~km}$ north of Mosul .The experiment include two factors, tillage system (conservation and conventional tillage) and seeding rates $\left(80,100\right.$ and $120 \mathrm{~kg} \cdot \mathrm{ha}^{-1}$ ), the seeds were planted at 11/1/2019 and $12 / 1 / 2019$ for the two locations respectively. The variety Adana registered and certified by the Iraqi Ministry of Agriculture. The experiment was applied as factorial experiment using split plots system by R.C.B.D with three replications. The main plots contained the two tillage and the sub plots contained seeding rates, The experimental unit area was $20 \mathrm{~m}^{2}$, the experiment was fertilized with $80 \mathrm{~kg}$. N.P.K.ha ${ }^{-1}$ recommended by Iraqi Ministry of Agriculture. The weeds samples were taken in April and the plants were dried in the oven at $72 \mathrm{~m}^{2}$ until the weight was stable, the plants were harvested at June, and data were collected for traits : number of narrow and broad leaves weeds and its weight, plant high $(\mathrm{cm})$, length of spike $(\mathrm{cm})$, No of grain per spike, number of spike. $\mathrm{m}^{-2}$ weight of 1000 grain, the yield amount gram. $\mathrm{m}^{2}$, and biological yield gram. $\mathrm{m}^{-2}$. Data were analyzed according to the method of the used design, and the differences between the means of each factors and their combinations compared by Duncan Multiple Range Test. 


\section{RESULTS AND DISCUSSION}

1- The effect of tillage system on studied characters: Table (1) showed nonsignificant differences between the tillage systems for number and weight of narrow and broad leaves weeds at the two location, the reason is the non-till cultivation in early years has no benefit in reducing the number of weeds . There were no significant differences between the two system in plant height. The results of statistical analysis indicated that conservation agriculture surpassed conventional system in no of spike, number of grains in spike, no. of spikes. $\mathrm{m}^{-2}$, weight of 1000 grain yield and the biological yield following by $(58 ., 8.87,58.42,1.62,78.57,182.44)$ respectively exceeded in Hamdaniya . Table number . of (4) shows significant differences between tillage system in Telkif the conventional tillage surpassed conventional tillage has excelled in the following characters, spike length, number of grain per spike, number of spikes. $\mathrm{m}^{-2}, 1000$ grains weight, grains yield. $\mathrm{m}^{-2}$ gram and the biological yield by grans. ${ }^{-2}$. By $(0.74 \mathrm{~cm}, 4.95,78.22,0.73,119.52$, $257.95 \mathrm{gm}$ ) respectively. The reason for this is that the soil retains more moisture without plowing, storing its longer and reducing the amount of water lost through evaporation, These results are consistent with that of Al-rijabo and Hussan (2011) and AL-badr (2012), those mentioned in conventional tillage have a very high evaporation rate and loss is rapid which is reflected in the growth of wheat plants.

2- Effect of seeding rate on study characters: Is was shown from significant differences between seeding rates for studied traits. non-significant differences for number and weight of narrow weeds at the two location weeds two locations. That due to the small number of narrow leaves weeds in those areas, this result is in acceptance with Antar (2013). The number of broad- leaves weeds in Hamdaniya site decreased when the seeding rate increased to 120 kg.h $\mathrm{h}^{-1}$ by ( 3.16 and 3.29 ) compared with 80 and $100 \mathrm{~kg} \cdot \mathrm{ha}^{-1}$ in, while dry weight decreased in seeding rate $120 \mathrm{~kg} \cdot \mathrm{h}^{-1}$ compared with 80 and $100 \mathrm{~kg} / \mathrm{h}^{-1}$ by (23.44 and 10.52 gm. $\mathrm{m}^{-2}$ ) respectively. At the Telkif site non-significant differences among the seeding rate for number of broad leaves weeds but the dry weight of the broad weeds decreased at the seeding rate $120 \mathrm{~kg} . \mathrm{h}^{-1}$ compare with the seeding rate $80 \mathrm{~kg} . \mathrm{h}^{-1}$ by 11.17 gran. $\mathrm{m}^{-2}$. The seeding rate was 120 $\mathrm{kg} \cdot \mathrm{h}^{-1}$ higher than the rate $80 \mathrm{~kg} \cdot \mathrm{ha}^{-1}$ for which character by 4.59 and $3.34 \mathrm{~cm}$ for both locations respectively. Seeding rate exceeds $120 \mathrm{~kg}$ compared the rate 80 and $100 \mathrm{~kg} \cdot \mathrm{h}^{-1}$ in spike length by 0.70 and $0.87 \mathrm{~cm}$ and the no of grains spikes by 7.12 and 8.93 respectively in Hamdaniya location ,compared only between high and low value, seeding rates $120 \mathrm{~kg} \cdot \mathrm{h}^{-1}$ higher than the seeding rate $100 \mathrm{~kg} \cdot \mathrm{h}^{-1}$ in spike length and no of grains / spike by 0.41 and 0.28 respectively . Seeding rate $120 \mathrm{~kg} \cdot \mathrm{ha}^{-1}$ was higher than another rates in no. of spikes. $\mathrm{m}^{-2}$ by 41.71 and 39.55 in Hamdaniya location while by $102.16,02.16$ and 43.66 in Telkif location. This is due to the higher number of plants per unit area by high seeding rate. These results are consistent with the results of AlLami and Shati (2010) and Ramadhan (2013), who confirmed the superior seeding rate in the number of spikes in unit area. The results of statistical 
analysis indicate significant differences between the seeding rates at the two location in grains yield and biological yield. The seeding rates 80 and 100 $\mathrm{kg} . \mathrm{h}^{-1}$ by 41.27 and 30.03 gram. $\mathrm{m}^{-2}$ for yield grains and 175.65 and 125.87 gm. $\mathrm{m}^{-2}$ for biological yield in Hamdaniya location. The seeding rate $120 \mathrm{~kg} \cdot \mathrm{h}^{-1}$ exceeded seeding rates 100 and $80 \mathrm{~kg} . \mathrm{m}^{-2}$ by Grain yield by 68.21 and 43.19 gm. $\mathrm{m}^{-2}$ respectively while the differences in biological yield were 176.99 and $150.35 \mathrm{gm} . \mathrm{m}^{-2}$, this is due to the large number of plants per unit area and the availability of large amounts of rain water in that season. These results are consistent with the results obtained by Ali and Aboud (2015) and Al-Jubouri (2012), which confirmed the increase in the crop yield when increasing the seeding rate as well as the availability a large amounts of rain water.

\section{3- Effect of conbination between tillage system and seeding rates levels for} studied traits: Table (3) indicate non-significant differences between means of tillage system and seeding rates combinations for number of narrow leaves weeds and dry weight , but the differences were significant for broads leaves weeds, the seeding rate of $120 \mathrm{~kg} / \mathrm{ha}^{-1}$ in conservation tillage exceeded the other rates in reducing the number of narrow leaves weeds by 2.17 and 3.28 all seeding rates in conversation were lower than the seeding rates in conventional tillage except for the seeding rates $120 \mathrm{~kg}$, which was non differ in the two types of tillage. The low number of broad weeds reflected on dry weight. So, decrease the dry weight in seeding rate $120 \mathrm{~kg}^{-h^{-1}}$ in two tillage system. At Talkef location the No. of broad leaves weeds was low at seeding rate $120 \mathrm{~kg} \cdot \mathrm{ha}^{-1}$ with conservation tillage which decreased other rates by 3.42 and 1.34, for dry weigh was non-significant differences between all seeding rate with the two systems except the seeding rate $120 \mathrm{~kg} \cdot \mathrm{h}^{-1}$ which was significantly low for all rates. The reason of the large number of plants at the seeding rate $120 \mathrm{~kg} \cdot \mathrm{h}^{-1}$ was due to increasing the competition of the wheat plants for the weeds. Non-significant differences among all seeding rate at the two tillage systems in plant height except seeding rate $80 \mathrm{~kg} . \mathrm{h}^{-1}$ with conventional system which was low as compared with all seeding rates at Hamdaniya location $(47.08 \mathrm{~cm})$ while the seeding rate with $120 \mathrm{~kg} \cdot \mathrm{h}^{-1}$ outperformed in plant height compared will all treatments whether in conservation or conventional tillage $(82.50 \mathrm{~cm})$. The seeding rate $100 \mathrm{~kg} \cdot \mathrm{h}^{-1}$ in conventional tillage low in plant high compared with other treatments. The seeding rate $80 \mathrm{~kg} . \mathrm{ha}^{-1}$ with conservation tillage superior than rest treatments in spike length ( 7.82 and $7.72 \mathrm{~cm}$ ) nz of grains per spike ( 41.89 and 39.05 ) in Al-Hamdania and Talkef respectively , the seeding rate $120 \mathrm{~kg} \cdot \mathrm{h}^{-1}$ superior on two seeding rates 80 and $100 \mathrm{~kg} \cdot \mathrm{h}^{-1}$ in no of spike. $\mathrm{m}^{-2}$ whether in conservation or conventional tillage in two location, This may be due to no. of plant per area unit. weight 1000 grains by the interaction the seeding rate 80 kg.ha ${ }^{-1}$ with conservation tillage superior on the 100 and $120 \mathrm{~kg} \cdot \mathrm{ha}^{-1}$ in conventional tillage in Hamdaniya location by 2.78 and 2.71 while the seeding rate $100 \mathrm{~kg} \cdot \mathrm{ha}^{-1}$ with conservation tillage superior than the other in Talkef location $(29.03 \mathrm{gm})$. The seeding rate $120 \mathrm{~kg} \cdot \mathrm{h}^{-1}$ in conservation tillage is 
superior at dry yield and biological yield compared with the other treatments whether at conservation or conventional tillage, the reason due to the No of plants in unit area and the provides moisture in conservation tillage in Hamdanyia location, while in Talkef location non-significant differences among the seeding rates in conservation tillage for dry weight and biological yield but the yield and biological yield are different conventional tillage according the seeding rates, this result are consistent with the findings of Antar et al (2013) whom confirmed the increase of yield by using conservation agriculture with high seeding rate.

Triticum aestivum L. تأثير نظم الحراثة ومعدلات البذار في نمو وحاصل الحنطة . والأدغال المرافقة لها.

\author{
أحمد مجيد عبدالله \\ سالم حمادي عنتر \\ قسم المحاصيل الحقلية / كلية الزراعة والغابات / جامعة الموصل/ العراق \\ Ahmed3079560@gmail.com
}

\begin{abstract}
الخلاصة
نفذت التجربة الحقلية خلال الموسم الزراعي الثتوي 2018-2019 في محافظة نينوى في موقعين , الاول قضاء الحمدانية 25-30 كم شرق مدينة الموصل , الثاني قضاء تلكيف 25-30 كم شمال مدينة الموصل, اشتملت التجربة عاملين الاول نظم الحراثة ( التقليدية والحافظة ) والثاني معدلات الثانية البذار

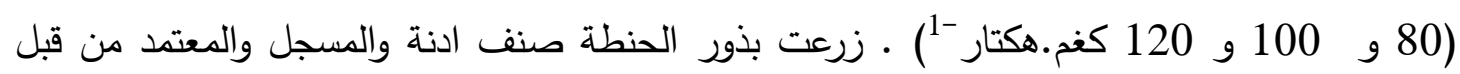

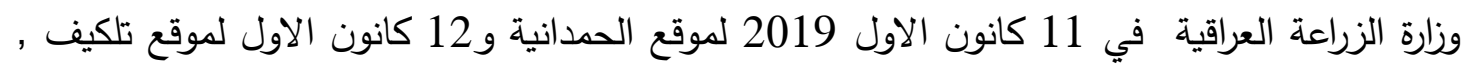

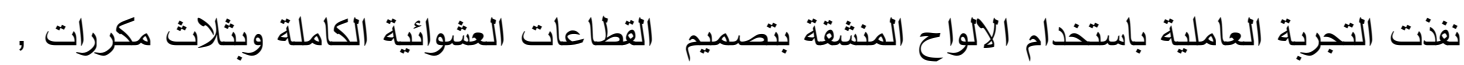

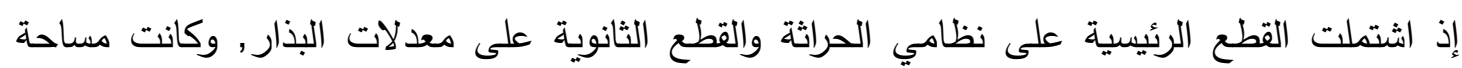

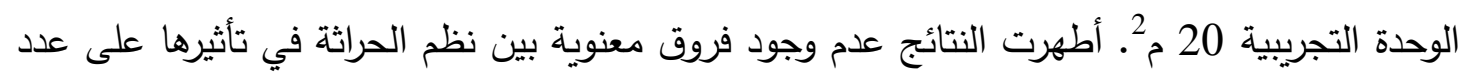
الادغال الرفيعة والعريضة الاوراق ووزنها الجاف في كلا الموقعين، تفوقت الزراعة الحافظة على الزراعة

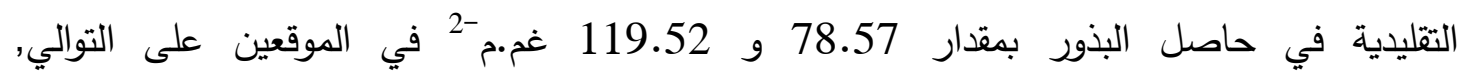


Mesopotamia J. of Agric.

Vol. (48) No. (3) 2020
ISSN: $2224-9796$ (Online)

ISSN: 1815 - 316 X (Print)

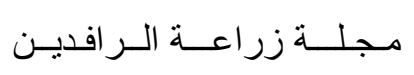
المجلد (48) العدد (3) 2020

Table (1): Effect of tillage systems on wheat growth, yield and its accompanying weeds.

\begin{tabular}{|c|c|c|c|c|c|c|c|c|c|c|c|}
\hline Tillage system & $\begin{array}{c}\text { No of narrow } \\
\text { leaves } \\
\text { weeds }\left(. \mathrm{m}^{-2}\right)\end{array}$ & $\begin{array}{l}\text { Dry weight } \\
\left(\mathrm{gm} . \mathrm{m}^{-2}\right)\end{array}$ & $\begin{array}{l}\text { No of broad } \\
\text { leaves } \\
\text { weeds. }\left(\mathrm{m}^{-2}\right)\end{array}$ & $\begin{array}{l}\text { Dry weight } \\
\left(\mathrm{gm} . \mathrm{m}^{-2}\right)\end{array}$ & $\begin{array}{l}\text { Plant hight } \\
(\mathrm{cm})\end{array}$ & $\begin{array}{c}\text { Spike } \\
\text { length } \\
\mathrm{cm})\end{array}$ & $\begin{array}{c}\text { No of grain } \\
\text { / spike }\end{array}$ & $\begin{array}{c}\text { No of } \\
\text { spikes. }\left(\mathrm{m}^{2}\right)\end{array}$ & $\begin{array}{l}\text { Weight of } \\
1000 \\
\text { grains } \\
\left(\mathrm{gm} / \mathrm{m}^{2}\right)\end{array}$ & $\begin{array}{c}\text { Yield } \\
\text { amount } \\
\left(\mathrm{kg} \cdot \mathrm{m}^{-2}\right)\end{array}$ & $\begin{array}{c}\text { Biological } \\
\text { yield } \\
\text { amount } \\
\left(\mathrm{kg} \cdot \mathrm{m}^{-2}\right)\end{array}$ \\
\hline & \multicolumn{11}{|c|}{ Hamdaniya location } \\
\hline Conservation & $1.94 \mathrm{a}$ & $2.46 \mathrm{a}$ & $17.67 \mathrm{a}$ & $113.95 \mathrm{a}$ & $52.92 \mathrm{a}$ & $7.18 \mathrm{a}$ & $34.73 a$ & $352.00 a$ & $29.17 \mathrm{a}$ & $297.41 \mathrm{a}$ & $1045.29 \mathrm{a}$ \\
\hline conventional & $1.78 \mathrm{a}$ & $2.35 \mathrm{a}$ & $20.39 a$ & $118.85 \mathrm{a}$ & $51.11 \mathrm{a}$ & $5.78 \mathrm{~b}$ & $25.86 \mathrm{~b}$ & $293.58 b$ & $27.55 \mathrm{~b}$ & $218.84 \mathrm{~b}$ & $862.85 \mathrm{~b}$ \\
\hline \multicolumn{12}{|c|}{ Talkef location } \\
\hline Conservation & $2.00 \mathrm{a}$ & $2.83 \mathrm{a}$ & $17.17 \mathrm{a}$ & $137.36 \mathrm{a}$ & $77.92 \mathrm{a}$ & $7.40 \mathrm{a}$ & $37.58 \mathrm{a}$ & $462.33 \mathrm{a}$ & $26.64 \mathrm{a}$ & $382.64 \mathrm{a}$ & $1371.18 \mathrm{a}$ \\
\hline conventional & $1.83 \mathrm{a}$ & $2.59 a$ & $19.22 \mathrm{a}$ & $144.15 \mathrm{a}$ & $66.53 \mathrm{a}$ & $6.66 \mathrm{~b}$ & $32.63 \mathrm{~b}$ & $384.11 \mathrm{~b}$ & $25.91 \mathrm{a}$ & $263.12 \mathrm{~b}$ & $1113.23 a$ \\
\hline
\end{tabular}

Table (2) Effect of seeding rates on wheat growth, yield and its accompanying weeds. Hamdaniya location.

\begin{tabular}{|c|c|c|c|c|c|c|c|c|c|c|c|}
\hline $\begin{array}{l}\text { Seeding rates } \mathrm{kg} \\
/ \mathrm{h}^{\mathrm{a} 1}\end{array}$ & $\begin{array}{c}\text { No of narrow } \\
\text { leaves } \\
\text { weeds }\left(. \mathrm{m}^{-2}\right)\end{array}$ & $\begin{array}{l}\text { Dry weight } \\
\left(\mathrm{gm} . \mathrm{m}^{-2}\right)\end{array}$ & $\begin{array}{l}\text { No of broad } \\
\text { leaves } \\
\text { weeds. }\left(\mathrm{m}^{-2}\right)\end{array}$ & $\begin{array}{l}\text { Dry weight } \\
\left(\mathrm{gm} \cdot \mathrm{m}^{-2}\right)\end{array}$ & $\begin{array}{l}\text { Plant hight } \\
\quad(\mathrm{cm})\end{array}$ & $\begin{array}{c}\text { Spike } \\
\text { length } \\
\mathrm{cm})\end{array}$ & $\begin{array}{l}\text { No of grain } \\
\text { / spike }\end{array}$ & $\begin{array}{c}\text { No of } \\
\text { spikes. }\left(\mathrm{m}^{2}\right)\end{array}$ & $\begin{array}{l}\text { Weight of } \\
1000 \\
\text { grains } \\
\left(\mathrm{gm} / \mathrm{m}^{2}\right)\end{array}$ & $\begin{array}{c}\text { Yield } \\
\text { amount } \\
\left(\mathrm{kg} \cdot \mathrm{m}^{-2}\right)\end{array}$ & $\begin{array}{l}\text { Biological } \\
\text { yield } \\
\text { amount } \\
\left(\mathrm{kg} \cdot \mathrm{m}^{-2}\right)\end{array}$ \\
\hline \multicolumn{12}{|c|}{ Hamdaniya location } \\
\hline 80 & $1.92 \mathrm{a}$ & $2.49 \mathrm{a}$ & $20.04 \mathrm{a}$ & $128.52 \mathrm{a}$ & $49.79 \mathrm{~b}$ & $7.00 \mathrm{a}$ & $35.65 \mathrm{a}$ & $308.18 b$ & $29.10 \mathrm{a}$ & $240.62 \mathrm{c}$ & $878.93 \mathrm{~b}$ \\
\hline 100 & $1.67 \mathrm{a}$ & $2.08 \mathrm{a}$ & $20.17 \mathrm{a}$ & $115.60 \mathrm{~b}$ & $51.88 a b$ & $6.30 \mathrm{~b}$ & $28.53 \mathrm{~b}$ & $310.33 b$ & $28.16 \mathrm{~b}$ & $251.86 \mathrm{~b}$ & $928.71 \mathrm{~b}$ \\
\hline 120 & $2.00 \mathrm{a}$ & $2.66 \mathrm{a}$ & $16.88 \mathrm{~b}$ & $105.08 \mathrm{c}$ & $54.38 \mathrm{a}$ & $6.13 \mathrm{~b}$ & $26.72 \mathrm{~b}$ & $349.88 \mathrm{a}$ & $27.83 \mathrm{~b}$ & 281.89 a & $1054.58 \mathrm{a}$ \\
\hline \multicolumn{12}{|c|}{ Talkef location } \\
\hline 80 & $1.92 \mathrm{a}$ & $2.59 \mathrm{a}$ & $19.04 \mathrm{a}$ & $145.05 \mathrm{a}$ & $72.29 \mathrm{~b}$ & $7.05 \mathrm{ab}$ & $35.80 \mathrm{a}$ & $369.67 \mathrm{c}$ & $25.87 \mathrm{~b}$ & $291.80 \mathrm{c}$ & $1174.33 \mathrm{~b}$ \\
\hline 100 & $1.83 \mathrm{a}$ & $2.72 \mathrm{a}$ & $18.38 \mathrm{a}$ & $143.34 \mathrm{ab}$ & $68.75 c$ & $6.81 \mathrm{~b}$ & $33.44 \mathrm{~b}$ & $428.17 \mathrm{~b}$ & $27.18 \mathrm{a}$ & $316.82 \mathrm{~b}$ & $1200.97 \mathrm{~b}$ \\
\hline 120 & $2.00 \mathrm{a}$ & $2.83 \mathrm{a}$ & $17.17 \mathrm{a}$ & $133.88 \mathrm{~b}$ & $75.63 a$ & $7.22 \mathrm{a}$ & $36.08 \mathrm{a}$ & $471.83 \mathrm{a}$ & $25.76 \mathrm{~b}$ & $360.01 \mathrm{a}$ & $1351.32 \mathrm{a}$ \\
\hline
\end{tabular}


Mesopotamia J. of Agric.

Vol. (48) No. (3) 2020
ISSN: $2224-9796$ (Online)

ISSN: 1815 - 316 X (Print)
مـلــــة زر اعـــة الــر افديـنـ

المجلد (48) العدد (3) 2020

Table (3): Effect of combination between the tillage system and seeding rates on wheat growth, yield and its accompanying weeds.

\begin{tabular}{|c|c|c|c|c|c|c|c|c|c|c|c|c|}
\hline Tillage system & $\begin{array}{l}\text { Seeding rates } \\
\mathrm{kg} / \mathbf{h a}^{-1}\end{array}$ & $\begin{array}{c}\text { No of } \\
\text { narrow } \\
\text { leaves } \\
\text { weeds }\left(. \mathrm{m}^{-2}\right)\end{array}$ & $\begin{array}{c}\text { Dry weight } \\
(\text { gm.m.2 }\end{array}$ & $\begin{array}{c}\text { No of broad } \\
\text { leaves } \\
\text { weeds. }\left(\mathbf{m}^{-2}\right)\end{array}$ & $\begin{array}{c}\text { Dry weight } \\
\left(\text { gm.m }^{-2}\right)\end{array}$ & $\begin{array}{l}\text { Plant hight } \\
\quad(\mathbf{c m})\end{array}$ & $\begin{array}{c}\text { Spike } \\
\text { length } \\
(\mathbf{c m})\end{array}$ & $\begin{array}{c}\text { No of } \\
\text { grain / } \\
\text { spike }\end{array}$ & $\begin{array}{c}\text { No of } \\
\text { spikes.(m²) }\end{array}$ & $\begin{array}{c}\text { Weight of } \\
1000 \\
\text { grains } \\
\left(\mathrm{gm} / \mathbf{m}^{2}\right)\end{array}$ & $\begin{array}{c}\text { Yield } \\
\text { amount } \\
\left(\text { kg.m }{ }^{-2}\right)\end{array}$ & $\begin{array}{c}\text { Biological } \\
\text { yield amount } \\
\left(\mathrm{kg}^{-2} \mathbf{m}^{-2}\right)\end{array}$ \\
\hline \multicolumn{13}{|c|}{ Hamdaniya location } \\
\hline \multirow{3}{*}{ Conservation } & 80 & $\begin{array}{c}1.83 \\
\mathrm{a}\end{array}$ & $\begin{array}{c}2.24 \\
a\end{array}$ & $\begin{array}{c}17.92 \\
\mathrm{~cd}\end{array}$ & $\begin{array}{c}133.22 \\
a\end{array}$ & $\begin{array}{c}52.50 \\
a\end{array}$ & $\begin{array}{c}7.82 \\
a \\
\end{array}$ & $\begin{array}{c}41.98 \\
\mathrm{a}\end{array}$ & $328.00 \mathrm{~b}$ & $\begin{array}{c}29.95 \\
a\end{array}$ & $\begin{array}{c}276.53 \\
b\end{array}$ & $\begin{array}{c}966.81 \\
b\end{array}$ \\
\hline & 100 & $\begin{array}{c}1.83 \\
a\end{array}$ & $\begin{array}{c}2.26 \\
a\end{array}$ & $\begin{array}{c}19.33 \\
\text { bc }\end{array}$ & $\begin{array}{c}107.54 \\
\text { b }\end{array}$ & $\begin{array}{c}52.50 \\
a\end{array}$ & $\begin{array}{c}6.81 \\
b\end{array}$ & $\begin{array}{c}31.25 \\
b\end{array}$ & $331.33 \mathrm{~b}$ & $\begin{array}{c}29.1 \\
b\end{array}$ & $\begin{array}{c}301.10 \\
\mathrm{a}\end{array}$ & $\begin{array}{c}1001.78 \\
b\end{array}$ \\
\hline & 120 & $\begin{array}{c}2.17 \\
a\end{array}$ & $\begin{array}{c}2.88 \\
a\end{array}$ & $\begin{array}{c}15.75 \\
d\end{array}$ & $\begin{array}{c}101.00 \\
b\end{array}$ & $\begin{array}{c}53.75 \\
a\end{array}$ & $\begin{array}{c}6.90 \\
b\end{array}$ & $\begin{array}{c}30.97 \\
b\end{array}$ & $396.67 \mathrm{a}$ & $\begin{array}{c}28.4 \\
\mathrm{C}\end{array}$ & $\begin{array}{c}314.62 \\
a\end{array}$ & $\begin{array}{c}1176.28 \\
a\end{array}$ \\
\hline \multirow{3}{*}{ Conventional } & 80 & $\begin{array}{c}2.00 \\
\mathrm{a}\end{array}$ & $\begin{array}{c}2.72 \\
\mathrm{a}\end{array}$ & $\begin{array}{c}22.17 \\
\mathrm{a} \\
\end{array}$ & $\begin{array}{c}123.81 \\
\mathrm{a} \\
\end{array}$ & $\begin{array}{c}47.08 \\
b\end{array}$ & $\begin{array}{c}6.18 \\
c\end{array}$ & $\begin{array}{c}29.32 \\
b\end{array}$ & $288.33 \mathrm{~d}$ & $\begin{array}{c}28.2 \\
\mathrm{c}\end{array}$ & $\begin{array}{c}204.72 \\
d\end{array}$ & $\begin{array}{c}791.04 \\
\mathrm{c} \\
\end{array}$ \\
\hline & 100 & $\begin{array}{c}1.50 \\
\mathrm{a}\end{array}$ & $\begin{array}{c}1.89 \\
\mathrm{a}\end{array}$ & $\begin{array}{c}21.00 \\
a b\end{array}$ & $\begin{array}{c}123.67 \\
\mathrm{a}\end{array}$ & $\begin{array}{c}51.25 \\
a b\end{array}$ & $\begin{array}{c}5.80 \\
c\end{array}$ & $\begin{array}{c}25.80 \\
\mathrm{c}\end{array}$ & $289.33 \mathrm{~d}$ & $\begin{array}{c}27.17 \\
\mathrm{~d}\end{array}$ & $\begin{array}{c}202.62 \\
d\end{array}$ & $\begin{array}{c}855.64 \\
c \\
\end{array}$ \\
\hline & 120 & $\begin{array}{c}1.83 \\
\mathrm{a}\end{array}$ & $\begin{array}{c}2.45 \\
a \\
\end{array}$ & $\begin{array}{c}18.00 \mathrm{c} \\
\mathrm{d}\end{array}$ & $\begin{array}{c}109.07 \\
b\end{array}$ & $\begin{array}{c}55.00 \\
\mathrm{a}\end{array}$ & $\begin{array}{c}5.37 \\
d\end{array}$ & $\begin{array}{c}22.47 \\
\mathrm{c} \\
\end{array}$ & $303.08 \mathrm{~cd}$ & $\begin{array}{c}27.24 \\
d\end{array}$ & $\begin{array}{c}249.17 \\
c \\
\end{array}$ & $\begin{array}{c}941.87 \\
b\end{array}$ \\
\hline \multicolumn{13}{|c|}{ Talkef location } \\
\hline \multirow{3}{*}{ Conservation } & 80 & $\begin{array}{c}1.67 \\
a\end{array}$ & $\begin{array}{c}2.36 \\
a\end{array}$ & $\begin{array}{c}19.00 \\
a b\end{array}$ & $\begin{array}{c}143.69 \\
a\end{array}$ & $\begin{array}{c}75.83 \\
b\end{array}$ & $\begin{array}{c}7.72 \\
a \\
\end{array}$ & $\begin{array}{c}39.05 \\
a\end{array}$ & $432.33 \mathrm{~b}$ & $\begin{array}{c}24.21 \\
d\end{array}$ & $\begin{array}{c}347.20 \\
b\end{array}$ & $\begin{array}{c}1387.51 \\
\mathrm{a}\end{array}$ \\
\hline & 100 & $\begin{array}{c}2.00 \\
a\end{array}$ & $\begin{array}{c}3.05 \\
a\end{array}$ & $\begin{array}{c}16.92 \\
b c\end{array}$ & $\begin{array}{c}143.02 \\
a\end{array}$ & $\begin{array}{c}75.42 \\
b\end{array}$ & $\begin{array}{c}7.11 \\
b\end{array}$ & $\begin{array}{c}36.53 \\
a b\end{array}$ & $456.67 \mathrm{~b}$ & $\begin{array}{c}29.03 \\
a\end{array}$ & $\begin{array}{c}395.70 \\
a\end{array}$ & $\begin{array}{c}1348.40 \\
a\end{array}$ \\
\hline & 120 & $\begin{array}{c}2.33 \\
\mathrm{a} \\
\end{array}$ & $\begin{array}{c}3.09 \\
a \\
\end{array}$ & $\begin{array}{c}15.58 \\
\mathrm{C} \\
\end{array}$ & $\begin{array}{c}152.38 \\
b\end{array}$ & $\begin{array}{c}82.50 \\
a \\
\end{array}$ & $\begin{array}{c}7.37 \\
a b\end{array}$ & $\begin{array}{c}37.17 \\
a b\end{array}$ & $498.00 \mathrm{a}$ & $\begin{array}{c}26.67 \\
\text { bc }\end{array}$ & $\begin{array}{c}405.02 \\
\mathrm{a}\end{array}$ & $\begin{array}{c}1377.61 \\
\mathrm{a} \\
\end{array}$ \\
\hline \multirow{3}{*}{ Conventional } & 80 & $\begin{array}{c}2.17 \\
\mathrm{a}\end{array}$ & $\begin{array}{c}2.82 \\
a \\
\end{array}$ & $\begin{array}{c}19.08 \\
a b\end{array}$ & $\begin{array}{c}146.42 \\
a\end{array}$ & $\begin{array}{c}68.75 \\
\mathrm{c} \\
\end{array}$ & $\begin{array}{c}6.38 \\
c \\
\end{array}$ & $\begin{array}{c}32.54 \\
\mathrm{~cd}\end{array}$ & $307.00 \mathrm{~d}$ & $\begin{array}{c}27.54 \\
a b\end{array}$ & $\begin{array}{c}236.40 \\
d\end{array}$ & $\begin{array}{c}961.14 \\
\mathrm{c}\end{array}$ \\
\hline & 100 & $\begin{array}{c}1.67 \\
a \\
\end{array}$ & $\begin{array}{c}2.39 \\
a \\
\end{array}$ & $\begin{array}{c}19.83 \\
\mathrm{a} \\
\end{array}$ & $\begin{array}{c}143.65 \\
a \\
\end{array}$ & $\begin{array}{c}62.83 \\
d\end{array}$ & $\begin{array}{c}6.52 \\
c \\
\end{array}$ & $\begin{array}{c}30.35 \\
d\end{array}$ & $399.67 \mathrm{c}$ & $\begin{array}{c}25.33 \\
\text { cd }\end{array}$ & $\begin{array}{c}237.94 \\
d\end{array}$ & $\begin{array}{c}1053.53 \\
b\end{array}$ \\
\hline & 120 & $\begin{array}{c}1.67 \\
a\end{array}$ & $\begin{array}{c}2.57 \\
a\end{array}$ & $\begin{array}{c}18.75 \\
a b\end{array}$ & $\begin{array}{c}142.37 \\
a\end{array}$ & $\begin{array}{c}68.75 \\
\mathrm{c} \\
\end{array}$ & $\begin{array}{c}7.09 \\
b\end{array}$ & $\begin{array}{c}34.99 \\
b c\end{array}$ & $445.67 \mathrm{~b}$ & $\begin{array}{c}24.86 \\
d\end{array}$ & $\begin{array}{c}315.00 \\
c\end{array}$ & $\begin{array}{c}1325.02 \\
a\end{array}$ \\
\hline
\end{tabular}




$$
\begin{aligned}
& \text { لم تظهر فروق معنوية بين معدلات البذار في تأثيرها على عدد الادغال الرفيعة والعريضة الاوراق في } \\
& \text { كلا الموقعين، تفوق معدل البذار } 120 \text { كغم.هكتار -1 على معدلي البذار } 80 \text { و } 100 \text { كغم.هكتار -1 في كمية فئل }
\end{aligned}
$$

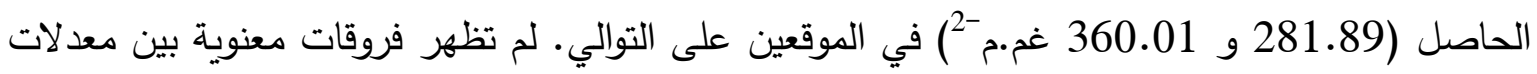

$$
\begin{aligned}
& \text { البذار سواء في الزراعة الحافظة او التقليدية في عدد الادغال الرفيعة الاوراق في الموقعين، بينما انخفضت } \\
& \text { اعداد الادغال العريضة الاوراق في معدل البذار } 120 \text { كغم.هكتار -1 في الزراعة الحافظة في الموقعين, افضل }
\end{aligned}
$$

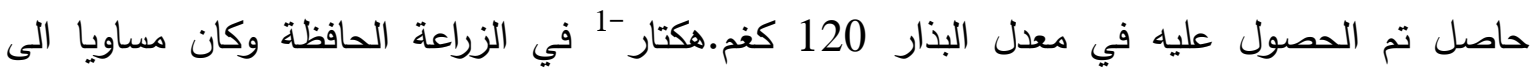

$$
\begin{aligned}
& 314.62 \text { و } 405.02 \text { غم.م -2 في موقعي الحمدانية وتلكيف على التوالي. } \\
& \text { الكلمات المفتاحية : الحنطة , نظام الزراعة , معدلات البذار . }
\end{aligned}
$$

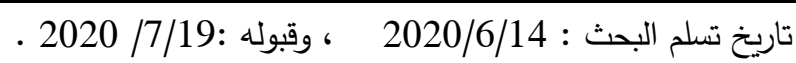

\section{REFERENCES}

Al-Badr , M.S.Jasim ; (2012). Effect Of Tillage System And Chemical Herbicides On Growth And Productivity Of Wheat (Triticum aestivum L.) And Associated Weeds. M.Sc. Thesis - College of Agriculture and Forestry University of Mosul.

Ali, H. A. and T. Y. Aboud (2015). The role of foliar fertilization in the growth and yield of wheat (Triticum aestivum L.) planted in different seed quantities and their effect on the characteristics of the yield and its components. AlMuthanna Journal of Agricultural Sciences. Volume 4 Issue (1): 1-13.

Al-Jubouri, R. M. A. H. (2012). The Effect Of Seed Rates On The Productivity Of Pure Lines And Their Combinations In Wheat Triticum aestivum L. Master thesis. College of Agriculture - University of Tikrit.

Al-Lami, S. H. K and R. K. Shati (2010). Effect of different rates of seed and bush pesticides on wheat quotient (Triticum aestivum L.) and associated bush growth. Al Furat Journal of Agricultural Sciences. Volume 2 Issue (1): 53-67.

Al-rijabo , A. A. and H. H. Hussain (2011). Effect of seed grading, seed rate and zero tillage planting method on growth, yield and its components of durum wheat (Triticum durum DESF.) under rainfed area. Mesopotamia J of Agric. Vol (39) No. (1).

Antar, S. H.; (2013). The effect of tillage systems and sowing rates on the growth and yield of soft wheat (Triticum aestivum L.) and the associated bushes in the hematological areas. Al-Rafidian Agriculture Journal Vol (41) No. (3).

Antar, S. H.; A. Hussin; M. R. Ahmed and N. Jasim (2013). Effect No Tillage And Seed Rates In Growth And Yield Of Wheat (Triticum aestivum L.) And Associated weed In Regions Different Rains. Thi-Qar Journal of Agricultural Research. 2 (2): 206 -221.

Bhattacharyya , R.; V. Prakash ; S. Kundu and H.S. Gupta (2006). Effect of tillage and crop rotations on pore size distribution and soil hydraulic conductivity in sandy clay loam soil of the Indian Himalayas. Soil \& Tillage Research., 86: 129-140. 
Mesopotamia J. of Agric. $\quad$ ISSN: $2224-9796$ (Online) مـجلـــة زر اعــة الــر افديـن Vol. (48) No. (3) $2020 \quad$ ISSN: 1815 - 316 X (Print) 2020 (3) المجلد (48) العدد

Blackshaw , R.E.; L.J. Molnar; G.W. Clayton; K.N. Harker and T. Entz (2007). Dry bean production in zero and conventional tillage. American Society of Agronomy, 99: 122-126.

Lemerle, . D.; R. D. Cousens; G. S. Gill S. J. Peltzer; M. Moerkerk; C. E. Murphy; D. Collins and B. R. Cullis (2004). Reliability of higher seeding rates of wheat for increased competitiveness with weeds in low rainfall environments. The Journal of Agricultural Science, 142 (4): 395 - 409.

Ramadhan, M.N; (2013). Tillage Systems and seedinh rates effect on yield components, seed yield and biological tield of Barley cultivars . jour. Basrah Res. Sci 19 (1) 33-46. 